\title{
The results of new studies of Quaternary sediments in the Kleszczów Graben, Szczerców Outcrop, Bełchatów Lignite Opencast Mine
}

\author{
Dariusz Wieczorek ${ }^{1}$, Andrzej Stoiński ${ }^{1}$, Dariusz Krzyszkowski ${ }^{2}$, \\ Lucyna Wachecka-Kotkowska ${ }^{3}$, Jarmila Krzymińska ${ }^{4}$ \\ ${ }^{1}$ Geoconsult Sp. z o.o., Kielce, Poland \\ ${ }^{2}$ Institute of Geography and Regional Development, University of Wroctaw, Poland \\ ${ }^{3}$ Department of Geomorphology and Palaeogeography, Faculty of Geographical Sciences, University of Łódź, Poland; \\ lucyna.wachecka@geo.uni.lodz.pl \\ ${ }^{4}$ Polish Geological Institute-National Research Institute, Branch of Marine Geology, Gdańsk, Poland
}

\begin{abstract}
The paper presents the results of new studies of Quaternary deposits filling the Kleszczów Graben in the Szczerców outcrop, Bełchatów Lignite Opencast Mine. Sedimentary successions were profiled in the fieldwork. Moreover, the borehole data were studied. Laboratory studies included: grain size analyses, analyses of shape and morphology of quartz grain (morphoscopy), analyses of anisotropy of magnetic susceptibility (AMS), palynological, malacological and ostracodological studies, as well as geochronometric $\left(\mathrm{C}^{14}\right)$ and geochemical $\left(\delta^{18} \mathrm{O} / \delta^{16} \mathrm{O}\right)$ measurements. The studies were carried out in 2009-2013 and resulted in discovering of some sedimentary formations as well as arranging geological cross-sections and synthetic lithostratigraphic profile. The following sedimantary formations have been distinguished: Folwark, Kuców, Czyżów, Ławki, Rogowiec, Aleksandrów, Piaski and Widawka, arranged into two structural units: the lower one - deformed, and the upper one - undeformed.
\end{abstract}

Key words: Quaternary, stratigraphy, Kleszczów Graben, Szczerców Outcrop, central Poland

\section{Introduction}

Studies of Quaternary deposits filling the Kleszczów Graben have been lasted for many years. Extraction of lignite from the Bełchatów Field, which started in 1981 (however the first mining operations date back to 1975), has allowed many researchers to conduct detailed examinations of Quaternary sediments in this area (e.g., Baraniecka et al. 1980, Czarnecki et al. 1992, Krzyszkowski 1992, 1995, 1996, Czubla 2001). Then, the onset of mining operations in 2002 in the Szczerców Field. First to remove the overburden, mainly of Quaternary deposits, helped Quaternary geologists to preliminarily correlate these deposits with the geological section of the Bełchatów Field. These works complement the palaeogeographic model of central Poland. The Bełchatów and Szczerców fields are separated by the Dębina salt diapir (see Sarnacka 1970, 1971, Wieczorek, Stoiński 2013) that was active during the Pleistocene (Baraniecka 1975a, b). It can be evidenced by the presence of both Zechstein deposits (main part of the diapir) at the sub-Quaternary surface and the overlying elevated Neogene and Pleistocene deposits (Ciuk 1980).
Diapir-related tectonic deformations are more distinct in the area of Szczerców Field (Ciuk 1973).

The reason to undertake the investigations was the continuation of regional research carried out from the late 1980s (e.g., Krzyszkowski 1992, 1995, 1996) on the one hand, and the need for updating the Detailed Geological Map of Poland 1:50 000, Szczerców sheet (Wieczorek, Stoiński 2013) on the other. Studies of Quaternary sediments in the Szczerców outcrop, especially of the Middle Polish Complex, were conducted by the authors from 2009 to 2013 (Fig. 1b). The exposing of new strata permitted to study Quaternary deposits in the Krasówka river valley area (Fig. 1b). The present study is also based on works of Król et al. (2007) and Kurpiewska (2010).

\section{Study area}

The study area is located in central Poland (Fig. 1) and straddles the Szczerców Basin and Bełchatów Plateau (Kondracki 2002). It is situated $20 \mathrm{~km}$ to the north of the maximum limit of Wartanian end moraines (e.g., 

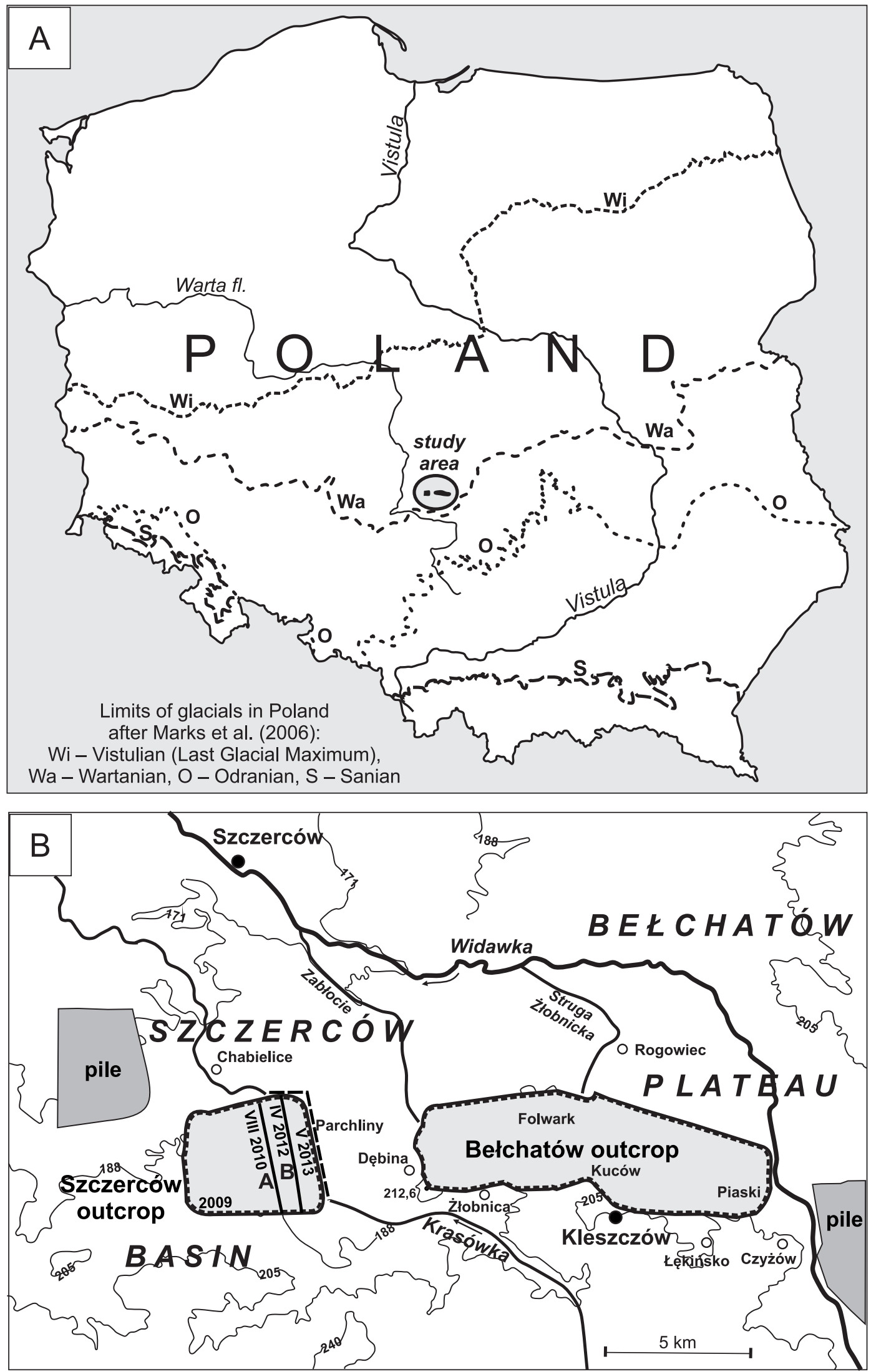

Fig. 1. Location of the study area on the map of Poland (A) and on the sketch of the Kleszczów - Szczerców vicinity (B); profiles and sections studied

A - Parchliny A (August 2010), B - Parchliny B (April 2012), C - (May 2013) 
Krzemiński 1997, Marks 2004, Marks et al. 2006, Turkowska 2006), which age is correlated with the oxygen stage 6 (MIS 6, Middle Polish Complex - see Lindner, Marks 2012).

\section{Methods and aim}

Fieldwork in the Szczerców Field was carried out mainly at the two highest mining levels of the outcrop (Fig. 2). A multi-method research approach was applied. The bore- hole sections and geological cross-sections were interpreted, and a palaeogeographical analysis was performed (e.g. Wieczorek, Stoiński 2013). The interpretation was based also on archived reports (e.g. Sarnacka 1970, 1971). The primary research goal was to identify the main structural and textural features of the Quaternary deposits, and thus sedimentological analysis (Miall 1978) was carried out, modified by Zieliński and Pisarska-Jamroży (2012). The textural analyses were made on several tens of sediment samples, including grain size analysis using the Folk and Ward technique (1957) and analyses of grain shape
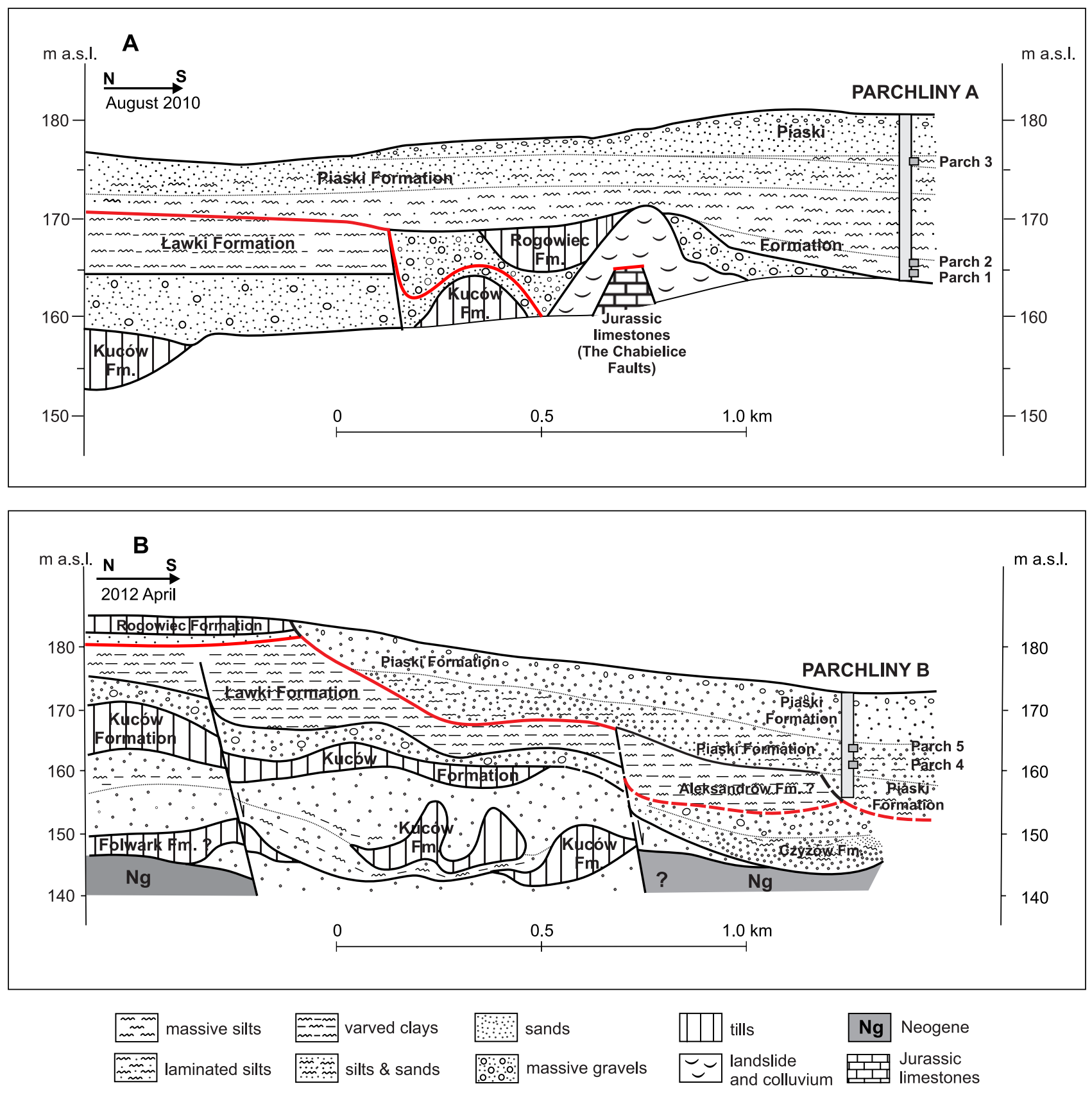

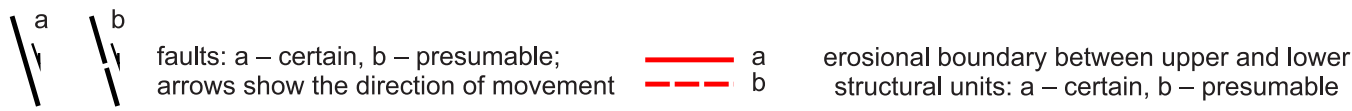

Fig. 2. Geological sketches of the Quaternary sediments within the eastern part of the Szczerców outcrop (near Parchliny) borehole profiles: A - Parchliny A (August 2010), B - Parchliny B (April 2012) 
and $0.8-1.0 \mathrm{~mm}$ surface morphology of quartz grain (morphoscopy) according to the Cailleux method (1942) modified by Goździk (1995). These indications were performed at the Department of Geomorphology and Palaeogeography Laboratory of the University of Łódź. The petrographic and heavy mineral analyses (Dobosz 2012) were carried out for Geconsult Kielce.

Geophysical methods were used for 10 samples of siltsand deposits. Determinations of anisotropy of magnetic susceptibility of the deposits (AMS) were performed at the Institute of Geophysics, Polish Academy of Sciences, in Warsaw by Dr Elżbieta Król (Wachecka-Kotkowska et al. 2014).

Palynological investigations (Kuszell, Iwanuś 2012) were carried out for Geconsult Kielce at the Institute of Geological Sciences of the University of Wrocław. Malacological (molluscs) and ostracodological (ostracods) studies were performed by Dr Jarmila Krzymińska at the Polish Geological Institute - National Research Institute, Marine Branch in Gdańsk-Oliwa.

Physico-chemical methods were used to determine the age of deposits and, basing on the $\delta^{18} \mathrm{O} / \delta^{16} \mathrm{O}$ ratio, to find out the palaeotemperatures. These proxies were determined by Dr Wojciech Drzewicki from the Institute of Geological Sciences of the University of Wrocław. Geochronological studies were based on the decay of ${ }^{14} \mathrm{C}$ radioactive isotope (Pazdur 2011, Michczyński 2012) and performed at the C14 Dating Laboratory of the Silesian University of Technology.

The major goal of this paper is to present the preliminary results, and also correlation of Quaternary deposits from the Szczerców outcrop located in the Kleszczów Graben carried out in the period 2009-2013, supplememnted in 2014-2015. The paper provides the characteristics of Quaternary depositional formations, their age and origin. The names of formations are cited after Krzyszkowski $(1992,1995,1996)$. They were recognized and documented in the nearby Bełchatów outcrop. Another goal was to try to correlate lithologically similar deposits in the Kleszczów Graben - to the west (Szczerców Field) and east (Bełchatów Field) of the Dębina Diapir, in order to indicate the regional similarities and differences for the stratotype Quaternary section of central Poland.

\section{Results}

\section{Folwark and Kuców Formations}

Deposits of the Folwark (Nida Glaciation) and Kuców (Sanian Glaciation) Formations have been so far more poorly recognized than the younger formations.

It has been found that tills and sands of the Folwark Formation (see Król et al. 2007) overlie a Neogene claysand complex represented by greenish clays, sandy clays, clayey silts and brownish sands (see Wieczorek, Stoiński 2013). They are overlain by glaciotectonically deformed sandy-gravel, till and clayey sands of the Kuców Formation (see Król et al. 2007).

Deposits of the Folwark and Kuców Formations are cut by faults. Petrographic studies of gravels from till indicate Kuców Formation - lithotype T2 known from the Bełchatów outcrop (Dobosz 2012, Krzyszkowski et al. 2015). There are also others tills, from the South Polish Glaciations, which differ in petrographic indices, perhaps due to the movement direction of ice-sheet advance.

The silt-sand-clay series (glaciolacustrine in origin) of the Sanian Glaciation in the Szczerców outcrop is relatively thick, locally up to $25 \mathrm{~m}$ (Kurpiewska 2010). Lithologically, these are silts and sandy silts with distinct lamination, grading into varved clays. They were deformated during time of sedimentation (flow deformations) and also tectonically (close to fault; see Fig. 2B). The main mineral constituent of this series is smectite, with subordinate illite and kaolinite, as well as calcite and quartz (Kurpiewska 2010). An ice-dammed lake series is also known from studies carried out by Król et al. (2007).

\section{Czyżów Formation}

South of the Chabielice Faults (part of the Kleszczów Graben, fig. 2A), there are varigrained white sands, probably representing the Czyżów Formation. They are characterized by lithofacies $S h$ and $S l$ - horizontally bedded and low-angle planar cross-bedded sands. Most likely, these sands represent fluvial sediments. They derived from erosion of older sediments, tills and also Neogene. This is confirmed by the presence of feldspars, fragments of crystalline rocks, quartz sand-stones and siliceous rocks, and sands are composed largely of quartz: 94-97\% (Dobosz 2012). The plant macroremains (probably of trees) have been collected from these rocks. They are currently under study (Myśkow et al. 2015).

\section{Lawki Formation}

The Ławki Formation deposits (Odranian Glaciation according to Krzyszkowski 1992, 1995 and Allen and Krzyszkowski 2008) are relatively common at the top of the lower, deformed structural unit (Fig. 2). The deposits are erosionally truncated along a boundary between the deformed lower structural level and the undeformed upper unit (Krzyszkowski 1992, 1995, 1996). These are tills (see Król et al. 2007), glaciofluvial sands and an icedammed lake series (see Kurpiewska 2010).

Malacological, ostracodological and geochemical studies were carried out on varved-like glacilacustrine deposits (grey silts and black clays) attaining a thickness of 20-30 metres. They were probably deposited in a closed lake (glacial in origin) of the ice-marginal zone (Wachecka-Kotkowska et al. 2012a) with a quiescent, but seasonally differing sedimentary conditions, inhabited by molluscs and cryophilic ostracods. The basin was progressively shallowing and transformed into lake dominated by currents. 


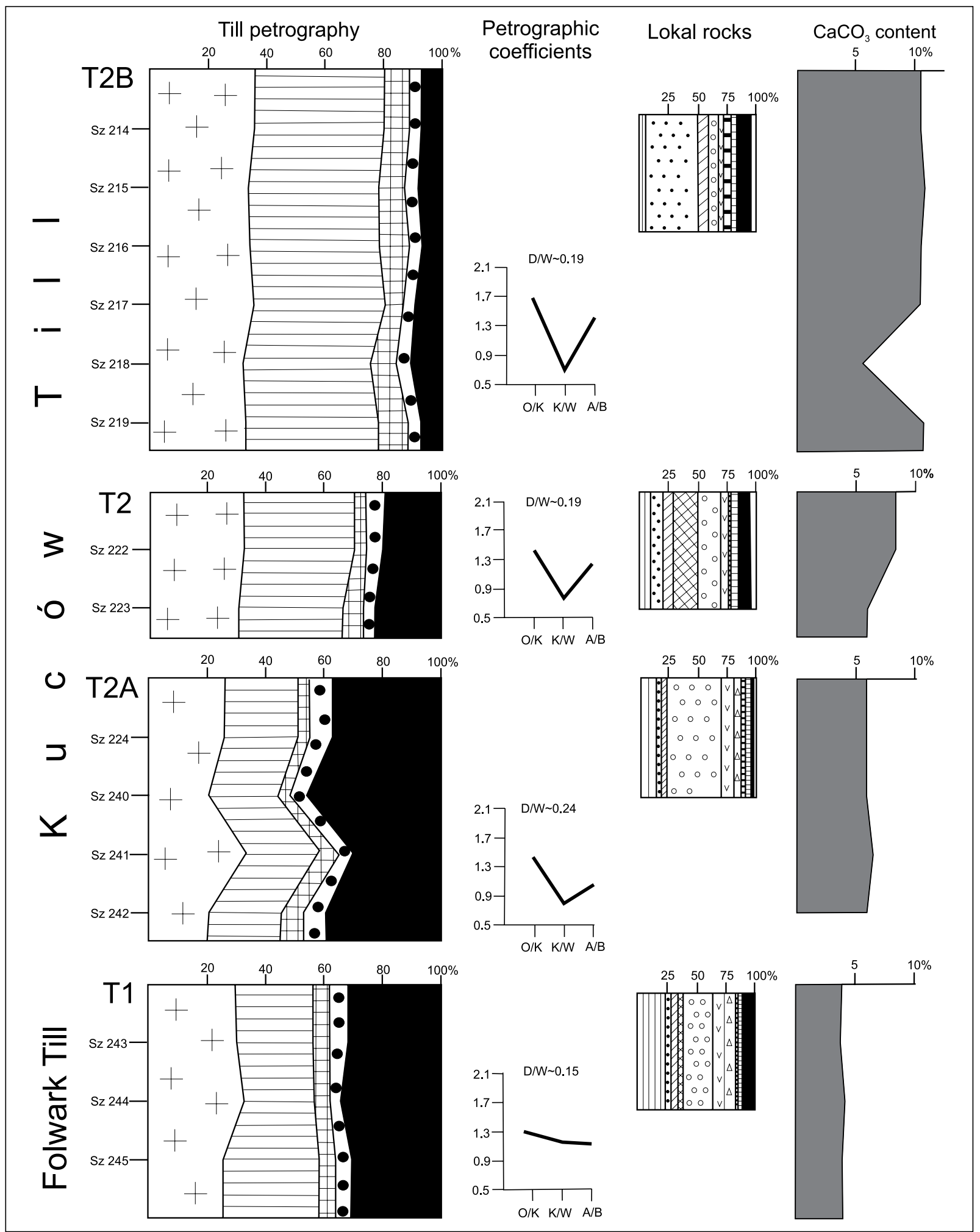

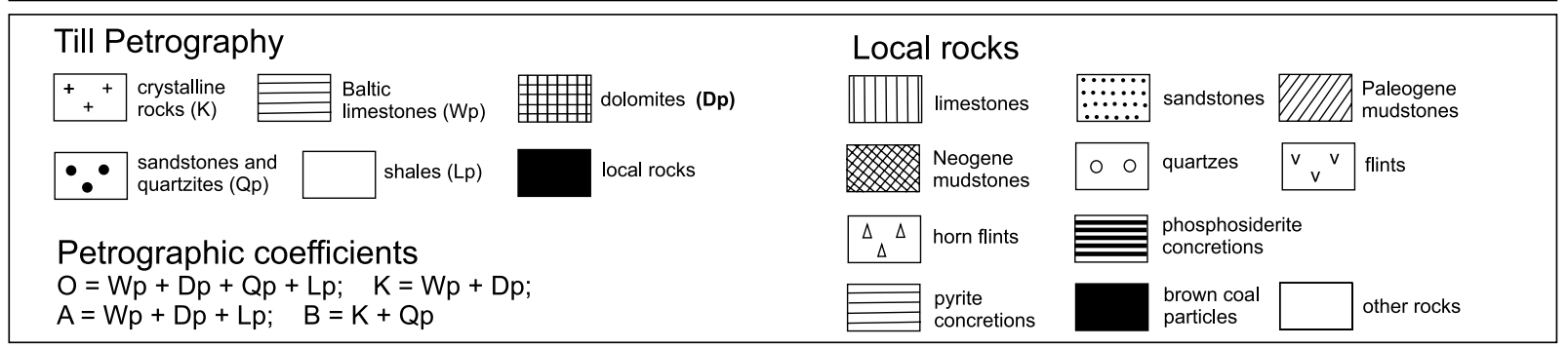

Fig. 3. Results of petrologic studies and correlation of tills from the eastern part of the Szczerców outcrop 


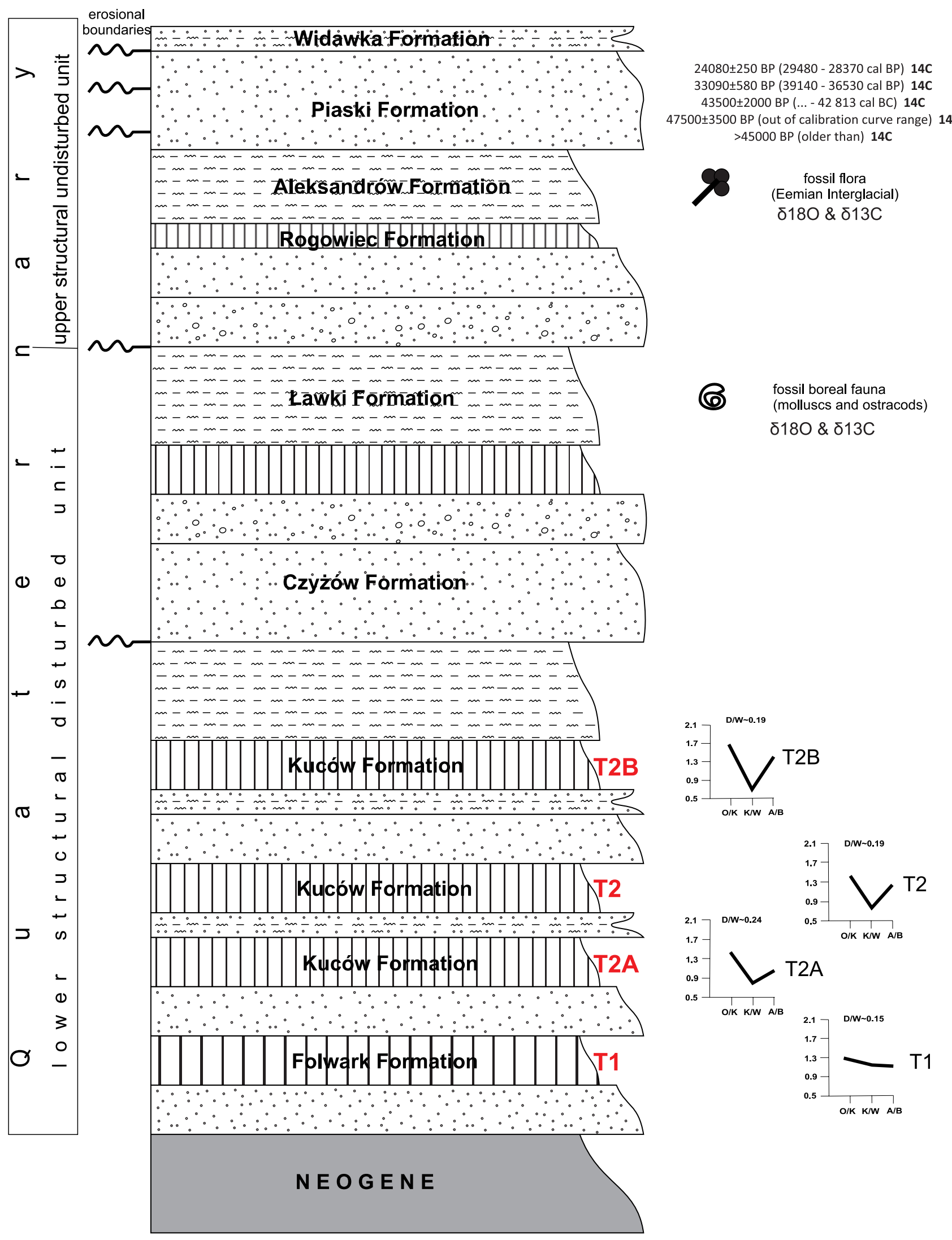

Fig. 4. Szczerców outcrop - general geological profile of the Quaternary sediments identified by different methods (sedimentological, palaeobotanical, palaeozoological and geochemical studies, as well as radiocarbon dating). For lithological explanations see Fig. 2 
The results of new studies of Quaternary sediments in the Kleszczów Graben, Szczerców Outcrop, Bełchatów Lignite

Table 1. Pollen zones in the Parchliny B profile, Szczerców outcrop, eastern excavation wall (Kuszell, Iwanuś 2012)

\begin{tabular}{clc}
\hline $\begin{array}{c}\text { Local pollen assemblage zones } \\
\text { (L PAZ) }\end{array}$ & \multicolumn{1}{c}{ Vegetation } & $\begin{array}{c}\text { Regional pollen asse blage zones } \\
\text { (R PAZ) }\end{array}$ \\
\hline P5 & $\begin{array}{l}\text { Warm-climate deciduous forests with lime-tree, oak, hornbeam } \\
\text { and hazel; hazel, which earlier occurred mainly in the under- } \\
\text { growth of mixed, oak-pine forests, could form warm-loving } \\
\text { shrubs and even hazel woods; an important diagnostic feature } \\
\text { in this level is the appearance of yew-tree (Taxus) - its presence } \\
\text { confirms the moderately warm climate with oceanic influences } \\
\text { Predominance of pine-oak forests; increase in hazel proportion at } \\
\text { the end of the period; hornbeam and lime-tree also appeared } \\
\text { Pixed, pine-birch forests, initially with a distinct proportion of } \\
\text { elm (P2), later with ash-tree (P3); warm-loving taxa of ivy (Hed- } \\
\text { era) and mistletoe (Viscum) appeared in the undergrowth; alder } \\
\text { shrubs with admixture of elm and ash-tree in wetland habitats } \\
\text { Birch-dominated forest communities with a low percentage of } \\
\text { herbal plants; moderate climate }\end{array}$ & E3 \\
P3, P2 & E2 \\
P1 & & E1 \\
\hline
\end{tabular}

\section{Rogowiec Formation}

The Rogowiec Formation deposits (Wartanian Glaciation after Krzyszkowski 1992, 1995, Allen and Krzyszkowski 2008, or Wartanian Stadial - upper part of the Odranian Glaciation after Lindner and Marks 2012) are represented by till (see Król et al. 2007) and glaciofluvial sands, which locally lie on erosional boundaries. Those deposits a few meters thick have been found in SW and NE corners of the outcrop.

\section{Aleksandrów Formation}

Along the axis of the Krasówka river valley, above the Rogowiec Formation, there are the Aleksandrów Formation deposits (see Kuszell, Iwanuś 2012) resting upon erosional boulders or glaciofluvial series, and dated at the Eemian Interglacial (see Tab. 1). Silts and clays in rhythmic deposition suggest the presence of a lake at that time, with a deposition of silts and clays showing the features of rhythmites (Wachecka-Kotkowska et al. 2013a, 2015). They are lithologically similar to the above-described varvites of the Lawki Formation.

Palynological studies show a vegetation succession from ascending interglacial period (level P1, E1) to its optimum (level P5, E4) (Tab. 1). Due to inaccessible walls of the opencast mine, the interglacial succession has not been fully examined in the upper parts of the section.

Remains of malacofauna were also found in muddy and organic deposits of the ancient lake. Eemian deposits of the Szczerców Field were earlier examined at the site as Podlas 18/21.5 (see Król et al. 2007). These sediments were destroyed during the exploitation.

\section{Piaski Formation}

Deposits of the Aleksandrów, Rogowiec, Ławki and, probably, Czyżów formations are discordantly overlain sediments of the Piaski Formation (Vistulian). In the east wall of the Szczerców outcrop, the lower part of this series was documented in 2010 and 2012 (Parchliny A and
B profiles, Fig. 2). These are fluvial and fluvio-deluvial sediments accumulated in periglacial conditions. Two series have been distinguished within this complex: the lower series of Middle Plenivistulian silt-sandy sediments (SFh, Sh - horizontally laminated sands/sandy silts) and the top horizon of Upper Plenivistulian sand sediments containing heavily aeolized grains. The detailed chronostratigraphic subdivision was possible due to radiocarbon dating (Pazdur 2011, Michczyński 2012). It points to the Middle Plenivistulian (MIS 3; $47 \mathrm{ka} \mathrm{BP}$ ) as the beginning of valley filling, and to the Upper Plenivistulian (MIS 2; $24 \mathrm{ka}$ BP) age of the fluvioperiglacial series (Wachecka-Kotkowska et al. 2012b, 2014). Based on a geomorphological analysis of the study area, it can be assumed that the Krasówka, Krasowa and Nieciecz rivers formed valleys draining the pre-existing post-Wartanian landforms, i.e. subglacial channels or kettle holes (Wieczorek, Stoiński 2013, Wachecka-Kotkowska et al. 2014).

\section{Widawka Formation}

The Vistulian deposits are locally covered by Holocene deposits of the Widawka Formation. The Holocene cover is represented mainly by grey and brownish-grey medium- and fine-grained sands and sandy silts of fluvial and fluvial-deluvial origin. They occur at the surface in the Krasówka river valley. Their thickness in the study area is about $2 \mathrm{~m}$.

\section{Conclusions}

The investigations carried out in the Szczerców outcrop allowed to confirm the occurrence of several formations in this region, namely: Folwark, Kuców, Czyżów, Ławki, Rogowiec, Aleksandrów, Piaski and Widawka Formations (see Fig. 4). In both the Bełchatów and Szczerców outcrops, the Quaternary is represented by two structural units, the deformed lower and the undeformed upper ones (Krzyszkowski 1992, Allen, Krzyszkowski 2008, Wachecka-Kotkowska et al. 2013b). 
Currently, the most disputable problems are those concerning the stratigraphic position of older tills and of the Middle Polish Complex sensu Lindner and Marks (2012), and, at the same time, corresponding with the studies of Krzyszkowski (1992) in the Bełchatów and Szczerców outcrops. Those studies did not prove the presence of the Ferdinandovian Interglacial, which could be a key to explain many questions on the Mesopleistocene of central Poland.

\section{Acknowledgements}

The authors thank the Management of the Bełchatów Lignite Opencast Mine, which is part of PGE Górnictwo i Energetyka Konwencjonalna S.A., for making it possible to study the Quaternary deposits in the period 20092013 and 2014-2015. Thanks are also to geologists Anna Skórzak and Katarzyna Adamczyk for technical and substantive assistance.

Part of the research was conducted during updating the Szczerców map sheet (735) of the Detailed Geological Map of Poland, scale 1:50 000. The work was carried out on request of the Minister of the Environment, and financed by the National Fund for Environmental Protection and Water Management.

\section{References}

Allen P., Krzyszkowski D., 2008. Till base deformation and fabric variation in lower Rogowiec (Wartanian, younger Saalian) till, Bełchatów outcrop, central Poland. Annales Societatis Geologorum Poloniae 78: 19-35.

Baraniecka M. D., 1971. Szczegółowa mapa geologiczna Polski w skali 1:50 000, arkusz Kamieńsk (M34-27B) wraz z objaśnieniami. Wydawnictwa Geologiczne Warszawa.

Baraniecka M. D., 1975a. Fazy tektoniczne w czwartorzędzie w środkowej części Niżu Polskiego. In: Materiały I Krajowego Sympozjum „Współczesne i neotektoniczne ruchy skorupy ziemskiej w Polsce”: 186-195. Wydawnictwa Geologiczne Warszawa.

Baraniecka M. D., 1975b. Zależność wykształcenia osadów czwartorzędowych od struktur i dynamiki podłoża w środkowej części Niżu Polskiego. Biuletyn Instytutu Geologicznego 288: 5-98.

Baraniecka M. D., Cieśliński S., Ciuk E., Dąbrowski A., Dąbrowska Z., Piwocki M., Werner Z., 1980. Budowa geologiczna rejonu bełchatowskiego. Przegląd Geologiczny 28(7): 381-391.

Cailleux A., 1942. Les actions eoliennes periglaciaires en Europe. Mémoires de la Société Géologique de France 41: 1-176.

Ciuk E., 1973. Wysad solny w Dębinie w rejonie bełchatowskiego złoża węgla brunatnego i jego stosunek do otoczenia utworów mezozoicznych i kenozoicznych w świetle historii i ostatnich badań. (Sprawozdania z posiedzeń naukowych Instytutu Geologicznego za okres 1 lipca-31 grudnia 1973 r.). Kwartalnik Geologiczny 17(3): $597-599$.

Ciuk E., 1980. Tektonika rowu Kleszczowa i jej wpływ na warunki powstania złoża węgla brunatnego. In: Przewodnik 52 Zjazdu Polskiego Towarzystwa Geologicznego, Bełchatów 11-14 września 1980r.: 56-70.

Czarnecki L., Frankowski R., Ślusarczyk G., 1992. Syntetyczny profil litostratygraficzny rejonu złoża „Bełchatów” dla potrzeb Bazy Danych Geologicznych. Górnictwo Odkrywkowe 3/4: 103-111.

Czubla P., 2001. Eratyki fennoskandzkie w utworach czwartorzędowych Polski środkowej i ich znaczenie stratygraficzne. Acta Geographica Lodziensia 80: 1-174.
Dobosz T., 2012. Badania mineralogiczno-petrograficzne osadów plejstoceńskich z Odkrywki w Szczercowie dla potrzeb reambulacji ark. Szczerców (735) SMGP w skali 1:50 000. Centralne Archiwum Geologiczne, Państwowy Instytut Geologiczny - Państwowy Instytut Badawczy w Warszawie (typescript in Polish).

Folk L.R., Ward W.C., 1957. Brazos river bar: a study in the significance of grain size parameters. Journal of Sedimentary Petrology 27(1): $3-26$.

Goździk J., 1995. Wybrane metody analizy kształtu ziarn piasków dla celów paleogeograficznych i stratygraficznych. In: E.Mycielska-Dowgiałło, J.Rutkowski (eds.) Badania osadów czwartorzędowych. Wydział Geografii i Studiów Regionalnych UW, Warszawa: 115-132.

Kondracki J., 2002. Geografia regionalna Polski. PWN Warszawa: $1-440$.

Król J., Hałuszczak A., Dobosz T., 2007. Dokumentowanie profili geologicznych z odsłonięć KWB Bełchatów i KWB Konin etap I (obejmujący część pilotażową). I Rejon KWB Bełchatów odkrywka Szczerców. Centralne Archiwum Geologiczne, Państwowy Instytut Geologiczny - Państwowy Instytut Badawczy w Warszawie.

Krzemiński T., 1997. Cechy rozwoju i zaniku lądolodu warciańskiego w środkowej Polsce. Acta Universitatis Lodziensis, Folia Geographica Physica 1: 47-65.

Krzyszkowski D., 1992. Czwartorzęd rowu Kleszczowa. Litostratygrafia i tektonika. Studia Geograficzne LIV. Wydawnictwo Uniwersytetu Wrocławskiego: 1-158.

Krzyszkowski D., 1995. An outline of the Pleistocene stratigraphy of the Kleszczów Graben, Central Poland. Quaternary Science Reviews 14: $61-83$.

Krzyszkowski D., 1996. Climatic control on Quaternary fluvial sedimentation in the Kleszczów Graben, Central Poland. Quaternary Science Reviews 15: 315-333.

Krzyszkowski D., Wachecka-Kotkowska L., Malkiewicz M., Krzymińska J., Ciszek D., Niska M., Myśkow E., Raczyk J., Wieczorek D., Stoiński A., 2015. Petrografia górnych glin zwałowych z odkrywki Szczerców KWB Bełchatów w świetle badań z 2014 i 2015 roku. [In:] J.Kordowski, P.Lamparski, S.Lisicki, M.Roman (red.) XXII Konferencja Naukowo-Szkoleniowa „Plejstocen Kotliny Płockiej oraz postglacjalna transformacja jej rzeźby", Gołaszewo 31.084.09.2015: 40-42.

Krzyszkowski D., Wachecka-Kotkowska L., Wieczorek D., Stoiński A., 2015. Petrography of glacial tills in the Szczerców Outcrop Central Poland - problems of stratigraphic interpretation. Studia Quaternaria 32(2): 99-108. DOI: http://dx.doi.org/10.1515/squa-2015-0009.

Kurpiewska I., 2010. Pozycja i wykształcenie osadów zastoiskowych odsłoniętych w wyrobisku Pola Szczerców (Rów Kleszczowa, niż polski). In: L.Marks, K.Pochocka-Szwarc (eds.) XVIII Konferencja Stratygrafia Plejstocenu Polski, Jeziorowskie. Państwowy Instytut Geologiczny - Państwowy Instytut Badawczy w Warszawie: 131.

Kuszell T., Iwanuś D., 2012. Badania palinologiczne osadów mułkowo-ilastych pobranych ze ściany poziomu 1-go w Odkrywce Szczerców KWB Bełchatów - profil Parchliny. Centralne Archiwum Geologiczne, Państwowy Instytut Geologiczny - Państwowy Instytut Badawczy w Warszawie (typescript in Polish).

Lindner L., Marks L., 2012. O podziale klimatostratygraficznym kompleksu środkowopolskiego w plejstocenie Polski. Przegląd Geologiczny 60(1): 36-45.

Marks L., 2004. Zasięg lądolodu zlodowacenia warty w Polsce. In: M.Harasimiuk, S.Terpiłowski (eds.) Zlodowacenia warty w Polsce. Wydawnictwo UMCS w Lublinie: 27-35.

Marks L., Ber A., Gogołek W., Piotrowska K. (eds.), 2006. Mapa geologiczna Polski w skali 1:500 000. Ministerstwo Środowiska \& Państwowy Instytut Geologiczny, Warszawa.

Miall A.D., 1978. Lithofacies types and vertical profile models in braided river deposits: A summary. In: A.D.Miall (ed.) Fluvial sedimentology. Canadian Society of Petroleum Geologist, Memoir 5: 597-604.

Michczyński A., 2012. Datowanie radiowęglowe 2 próbek (PARCH 4, PARCH 5). Raport nr 38/2012. Laboratorium Radiowęglowe, Instytut Fizyki, Politechnika Śląska. Centralne Archiwum Geologiczne, Państwowy Instytut Geologiczny - Państwowy Instytut Badawczy w Warszawie (typescript in Polish).

Myśkow E., Krzyszkowski D., Wachecka-Kotkowska L., 2015. Makroskopowe szczątki roślinn $\mathrm{z}$ mezoplejstoceńskich osadów odkry- 
wki Szczerców KWB Bełchatów. VII Konferencja Paleobotaniki Czwartorzędu „Dynamika zmian roślinności Niżu Polskiego w dobie późnoglacjalnych zmian klimatu i narastania antropopresji w holocenie. Łódź, 10-12 czerwca 2015: 45-47.

Pazdur A., 2011. Datowanie radiowęglowe 3 próbek (PARCH 1, PARCH 2, PARCH 3). Raport nr 2/2011. Laboratorium Radiowęglowe, Instytut Fizyki, Politechnika Śląska. Centralne Archiwum Geologiczne, Państwowy Instytut Geologiczny - Państwowy Instytut Badawczy w Warszawie (typescript in Polish).

Sarnacka Z., 1970. Objaśnienia do Szczegółowej mapy geologicznej Polski w skali 1:50 000, arkusz Szczerców (M34-27A). Wydawnictwa Geologiczne Warszawa.

Sarnacka Z., 1971. Szczegółowa mapa geologiczna Polski w skali 1:50 000, arkusz Szczerców (M34-27A). Wydawnictwa Geologiczne Warszawa.

Turkowska K., 2006. Geomorfologia regionu łódzkiego. Wydawnictwa Uniwersytetu Łódzkiego: 1-238.

Wachecka-Kotkowska L., Krzyszkowski D., Pazdur A., Klaczak K., 2011. Wiek wypełnienia doliny Krasówki w świetle datowań C14, Pole Szczerców KWB „Bełchatów”. In: IX Zjazd Geomorfologów Polskich, Poznań: 161-162.

Wachecka-Kotkowska L., Krzyszkowski D., Krzymińska J., 2012a. Climatic Control on Saalian Glacilacustrine Sedimentation in the Kleszczów Graben, Central Poland, Case of the Ławki Formation. In: INQUA-SEQS 2012 Meeting At the Edge of the Sea: Sediments, Geomorphology, Tectonics and Stratigraphy in Quaternary studies, Sassari, Sardinia, Italy, September 26-27, 2012: 100-101.

Wachecka-Kotkowska L., Krzyszkowski D., Klaczak K., 2012b. Age of the Krasówka river valley filling in the light of C14 dating, Szczerców field, Bełchatów Outcrop, Central Poland. In: FLAG Biennal Meeting 2012 New insight on the Quaternary evolution of the Moselle River and its tributaries (Luxembourg, France, Germany), Remich, Luxembourg, September 2-7, 2012: 44.
Wachecka-Kotkowska L., Krzyszkowski D., Drzewicki W., $2013 a$. Development of the Eemian palaeolake in the Kleszczów Graben, Szczerców Field, Belchatów Outcrop, Central Poland. In: International Field Symposium Palaeolandscapes from Saalian to Weichselian, South Eastern Lithuania June 25-30, 2013: 102-103.

Wachecka-Kotkowska L., Krzyszkowski D., Krzymińska J., Drzewicki W., Wieczorek D., Stoiński A., 2013b. Geneza, litologia i stratygrafia osadów czwartorzędowych rowu Kleszczowa w świetle nowych badań w odkrywce Szczerców. In: A.Kostrzewski, G.Rachlewicz, M.Woszczyk (eds.) VI Seminarium Geneza, litologia i stratygrafia utworów czwartorzędowych. Poznań, 14-15 listopad 2013: 168-172.

Wachecka-Kotkowska L., Krzyszkowski D., Król E., Klaczak K., 2014. Middle Weichselian Pleniglacial fluvial erosion and sedimentation in the Krasówka river valley, Szczerców field, Bełchatów open cast mine, central Poland. Annales Societatis Geologorum Poloniae 84(4): 323-340.

Wachecka-Kotkowska L., Krzyszkowski D., Malkiewicz M., Krzymińska J., Niska M., Myśkow E., Mirosław-Grabowska J., Raczyk J., Wieczorek D., Stoiński A., 2015. Ewolucja środowiska przyrodniczego od schyłku zlodowacenia środkowopolskiego do plenivisulianu (MIS6-MIS3) na przykładzie stanowiska „Parchliny 2014” - wstępne wyniki badań. [In:] J.Kordowski, P.Lamparski, S.Lisicki, M.Roman (eds.) XXII Konferencja Naukowo-Szkoleniowa „Plejstocen Kotliny Płockiej oraz postglacjalna transformacja jej rzeźby”, Gołaszewo 31.08-4.09.2015: 104-107.

Wieczorek D., Stoiński A., 2013. Szczegółowa mapa geologiczna Polski w skali 1:50 000, arkusz Szczerców (735) wraz z objaśnieniami. Centralne Archiwum Geologiczne, Państwowy Instytut Geologiczny - Państwowy Instytut Badawczy w Warszawie.

Zieliński T., Pisarska-Jamroży M., 2012. Jakie cechy litologiczne warto kodować, a jakie nie? Przegląd Geologiczny 60(7): 387-397. 